\title{
Herbivory of sympatric elk and cattle on Lincoln National Forest, south-central New Mexico
}

\author{
Heather H. Halbritter and Louis C. Bender ${ }^{*}$
}

\begin{abstract}
Background: Wildlife and livestock grazing are important products of forest ecosystems, but can be controversial. Herbivory by North American elk and domestic cattle is a contentious management issue throughout western North America, often driving management proposals to decrease cattle and elk numbers based on perceived overutilization of forages. Such observations are often site level rather than landscape, and may confuse ecological sustainability with desired conditions.

Methods: We used line transects to document vegetation composition, structure, and grazing and browsing utilization for 4 key habitat types: mountain meadows, aspen, thinned conifer, and burned conifer on Lincoln National Forest, New Mexico, USA. We documented relative habitat use of these types by elk, mule deer, and cattle and modeled relative use on residual grass biomass of mountain meadows and browse utilization of forested types. We determined diets and diet quality of elk and cattle to assess degree of competition.

Results: Use of grasses in meadows was below management thresholds, and combined elk, cattle, and deer relative habitat use accounted for $<14 \%$ of the variance in residual stubble height of Poa pratensis, the most abundant grass. Palatable browse was limited in habitat types $\left(<107\right.$ stems ha $\left.a^{-1}\right)$, use was generally high, and elk presence was correlated with the majority of browsing. Elk and cattle diets did not significantly overlap (Schoener's index $0.54-0.57$ ); elk fed primarily on deciduous shrubs (34 \%-55\% of annual diets) and cattle on grass (72\%-77\%). Digestibility and crude protein levels of cattle diets and body condition of elk indicated high quality diets for cattle and marginal-good quality diets for elk.

Conclusions: At observed stocking levels and densities, cattle and elk were not competing for forage based on diet similarity, nor were key habitat types being used beyond sustainable levels. Low browse availability indicates that opportunity exists to increase forage availability on Lincoln National Forest, and thus maintain or increase populations without increasing impacts to plant communities. Management actions that address increased stand densities and forest encroachment of meadows, a result of altered historical disturbance regimes, could increase distribution, quantity, and quality of forage.
\end{abstract}

Keywords: Browsing; Cattle; Carrying capacity; Elk; Grazing; Herbivory; Nutrition

\section{Background}

Wildlife and livestock grazing are important products of forest ecosystems, but conflicts can arise when co-use is perceived to negatively affect users or the ecosystem. Balancing elk (Cervus elaphus), cattle (Bos taurus), and habitat conditions is a challenging management issue throughout the western United States (Kay 1997; National Research Council 2002; Vavra 2005), where management for the full continuum of forest resources, including

\footnotetext{
* Correspondence: Ibender@nmsu.edu

Extension Animal Sciences and Natural Resources, New Mexico State University, Las Cruces, NM, USA
}

wildlife and livestock forage, is mandated on National Forests by the Multiple-Use Sustained-Yield Act of 1960 (Public Law 86-517), the Forest and Rangeland Renewable Resources Planning Act of 1974 (Public Law 93-378), and the National Forest Management Act of 1976 (Public Law 94-588). Through foraging activities, elk and livestock can significantly impact plant community structure, function, health, and composition (Chadde and Kay 1991; Fleischner 1994; Ripple and Larsen 2000; Ripple et al. 2001; National Research Council 2002; Peinetti et al. 2002; Vavra 2005). These changes can be positive (McNaughton 1976; Vavra 2005; Stewart et al. 2006) or negative (Severson

\section{Springer}


and Medina 1983; Riggs et al. 2005). This distinction depends in part on the intensity of use and characteristics of the plant community (Georgiadis et al. 1989; Hamilton et al. 1998; De Mazancourt et al. 1998; Alstad et al. 1999; Stewart et al. 2006).

Much controversy regarding herbivory has arisen because of negative impacts on vegetation communities. Recruitment of preferred browse species such as Salix spp. and Populus tremuloides can be eliminated by large populations of elk (Chadde and Kay 1991; Relva and Veblen 1998; Kay and Bartos 2000). Similarly, cattle herbivory can affect sustainability of herbaceous and woody forages (Fleischner 1994; Vavra 2005). Foraging by large herbivores can be especially contentious in areas where forage is managed for multiple uses, including livestock forage and wildlife habitat (Kay 1997; National Research Council 2002; Vavra 2005).

Such a situation exists on Lincoln National Forest (LNF) in the Sacramento Mountains of south-central New Mexico, where perceived impacts of herbivory have resulted in management recommendations to lower cattle and elk numbers in conflict areas (Hurd 2002; Hurd et al. 2004; Halbritter and Bender 2011b). Conflicts involve perceived inadequate residual biomass of grasses in mountain meadow communities, which is attributed to elk grazing, cattle grazing, or both, dependent upon user group. Further, the issue is complicated by hypothesized negative impacts of inadequate residual herbaceous biomass on habitat quality of prey of the endangered Mexican spotted owl (Strix occidentalis) (Hurd 2002; Hurd et al. 2004). Thus, the conflict includes both ecological carrying capacity (the maximum number of herbivores supportable by the standing plant biomass; in this case, are elk and cattle overabundant with regard to sustainability of plant communities and are they limiting performance of each other?) and sociological carrying capacity (the maximum number of animals tolerable for some desired ecological condition; in this case, is combined large herbivore grazing - regardless of level or sustainability negatively impacting Mexican spotted owls?) (definitions following Caughley 1979 and Carpenter et al. 2000). Despite this, arguments are invariably couched in the context of unsustainable utilization of meadows by large herbivores, with consequent claims that one or both species are "over carrying capacity" in the ecological context.

Much of the data driving these conflicts and resultant management actions on LNF were based upon only a few indicator sites and included no direct knowledge of individual herbivore contributions to perceived impacts or preferences for key foraging habitats. Moreover, while concurrent use by elk and cattle is anecdotally believed to decrease forage quantity and/or quality available for the other herbivore, no data is available on comparative habitat use or diets attained by elk or cattle in LNF. Thus, to address the issue of ecological carrying capacity only, our goal was to identify the degree of use and impacts of elk and cattle foraging across key habitat cover types in LNF. Our objectives included: 1) determine plant community composition and relative use by large herbivores, 2) determine levels of browsing of key woody plants, 3) quantify degree of grazing on herbaceous communities, and 4) determine diets and relative diet quality of elk and cattle.

\section{Methods}

\section{Study area}

Our study area encompassed much of the Sacramento Ranger District of Lincoln National Forest (LNF), located in the Sacramento Mountains of south-central New Mexico (approximately 32 $49^{\prime} 59^{\prime \prime}$ N, 105 $43^{\prime} 01^{\prime \prime}$ ' W; Fig. 1). The Sacramento Ranger District manages 182,278 ha of the LNF. Average high temperature in June is $23{ }^{\circ} \mathrm{C}$ and average low January temperature is $-7{ }^{\circ} \mathrm{C}$. Annual precipitation averages $67 \mathrm{~cm}$ with $>50 \%$ falling June-September. Annual snowfall averages $183 \mathrm{~cm}$. Annual precipitation was 0.94, 0.82, and 1.36 of normal, 2004-2006, respectively. Precipitation during the May-October growing and cattle grazing season was $0.69,0.77$, and 1.82 of normal, 2004-2006, respectively.

Vegetation communities in the Sacramento Mountains are very diverse due to differences in elevation and precipitation. Desert scrub-grassland habitat covers the lower foothills from 1380 to $1830 \mathrm{~m}$ (Kaufmann et al. 1998). Pinus edulis-Juniperus monosperma woodland occurs along with areas of dense Quercus gambelii above 1700-1800 m, usually along canyons and ridges. Pinus ponderosa is found above 2100 m typically mixed with Pinus edulis-Juniperus monosperma or Pseudotsuga menziesii. Above 2200-2500 m, the mountains are dominated by a mixed conifer forest, consisting of Abies concolor, Pseudotsuga menziesii, Pinus ponderosa, Pinus strobiformis, and occasionally Picea pungens or Picea engelmannii. Pockets of Populus tremuloides are found mixed within the conifers, rarely in pure stands. Mountain meadows are numerous at high elevations and comprise $<5 \%$ of the landscape. Mountain meadows and other open habitats are much reduced in LNF as compared to historical coverage primarily because of altered fire regimes and reduced timber harvest (Kaufmann et al. 1998; Frost et al. 2007). Similarly, stem densities in forested stands are generally much higher than historically again because of altered natural disturbance regimes and reduced timber harvest (Kaufmann et al. 1998; Frost et al. 2007).

Annual population estimates for elk in the surrounding game management unit have varied greatly, 1998-2006. Corroboration of estimators from 2003 to 2007 suggested an elk density of 0.7-0.9+ elk. $\mathrm{km}^{-2}$ (Bender 2007). During our study the Sacramento Ranger District managed 38 


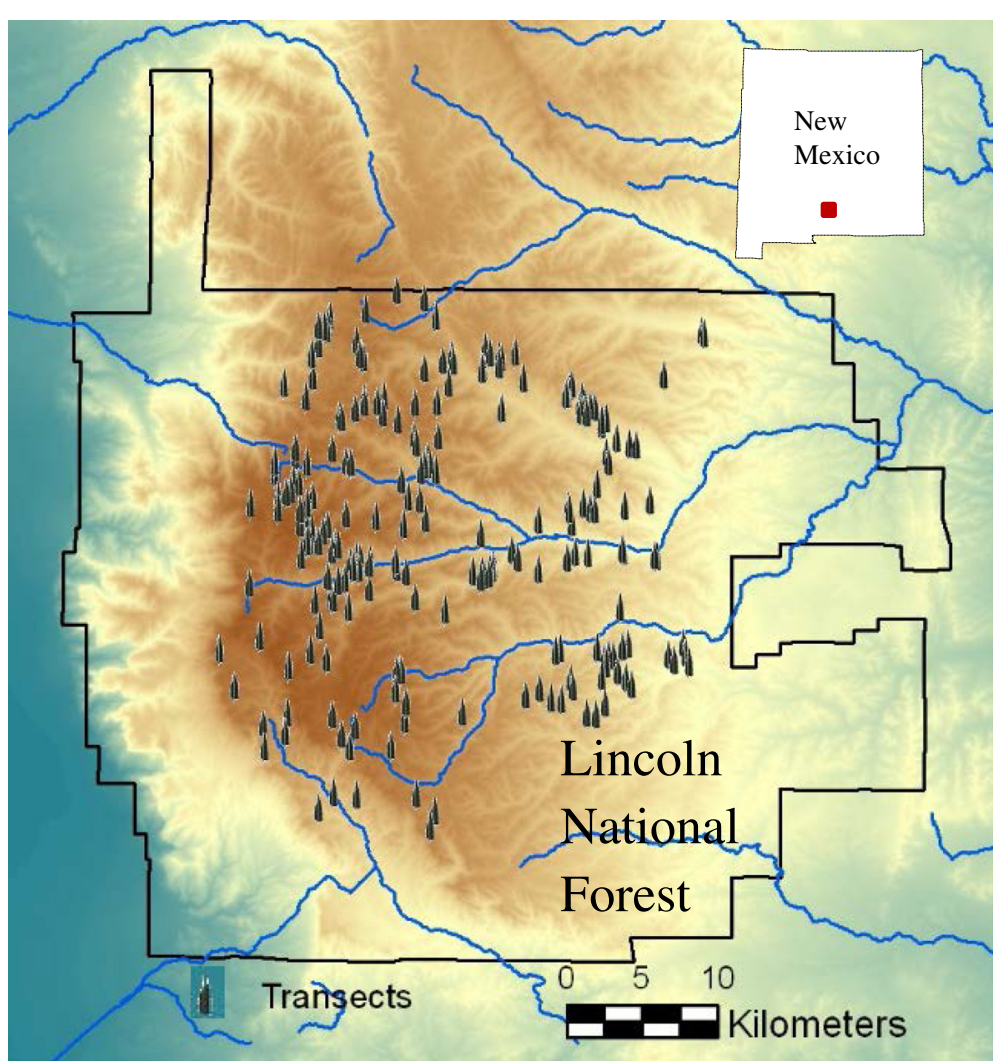

Fig. 1 Digital elevation map of the Sacramento Ranger District (solid line) showing locations of sampling transects, Lincoln National Forest, southcentral New Mexico, USA. Dashed inset shows location of figure (red polygon) within the state of New Mexico

grazing allotments with 34 permittees. The majority of our study area was in the spring-autumn range of the Sacramento allotment, which encompassed approximately 44,744 ha. In 2004-2006, approximately 330 permitted cattle grazed the allotment for a density of 0.7 cows $\cdot \mathrm{km}^{-2}$. Grazing followed a deferred rotation system from midMay through October, with 2 pastures alternating annually between early summer (mid-May through early August) and late summer (early August through October) grazing. Each pasture was grazed by cattle during 1 of the periods each year, but not the same period in consecutive years.

\section{Vegetation surveys}

We surveyed vegetation composition and structure during mid-late September, 2005 and 2006, which was approximately the peak of herbaceous species growth. We defined vegetation types from a GIS database, then randomly selected 25-30 stands of each of 4 key vegetation types: mountain meadow, aspen (Populus tremuloides), thinned conifer, and burned conifer. We selected these types based on preferences for elk and cattle foraging use in the montane habitats of LNF (Wright 2000; Hurd 2002).

We established a single random $100-\mathrm{m}$ transect per stand replicate, for a total of 25-30 replicates per habitat type. We tallied ground cover (i.e., soil, rock, plant, litter) every $1 \mathrm{~m}$ along transects. If cover was a plant, we identified it to species; if a grass, we measured its average leaf height ("stubble height") by pulling the blades of grass up and measuring their height (Allison et al. 2007). We determined mean residual stubble heights (RSH) by species and compared these to published standards to determine grazing intensity (Allison et al. 2007). If the cover was not a grass, we located the nearest grass plant to the point and recorded its species and stubble height. We calculated $90 \%$ CIs around mean RSH to see if mean RSH differed from standards; if the standard was included in $90 \%$ CIs, there was no difference. We used a linear mixed model (West et al. 2014) with year as a random effect to test for differences among ground cover type, habitat type, and year, specifically testing the ground cover type $\times$ habitat type $\times$ year interaction.

We determined densities of woody shrubs $(<5.1 \mathrm{~cm}$ $\mathrm{dbh})$ and trees $(\geq 5.1 \mathrm{~cm} \mathrm{dbh})$ using the point-centered quarter method (Cottam and Curtis 1956), with points occurring every $25 \mathrm{~m}$ along transects. We determined percent canopy cover using a spherical densitometer (Lemmon 1956) every $25 \mathrm{~m}$ along the 100-m transect. We took 4 estimates at each point, 1 for each cardinal direction, and estimated percent canopy cover by averaging the estimates. We modeled total plant cover and 
woody stem densities as a function of percent canopy cover using linear regressions (Zar 1996). We used a linear mixed model (West et al. 2014) with year as a random effect to test for differences in tree and shrub total density among habitat type and year, specifically testing the habitat type $\times$ year interaction.

We used stepwise multiple regression (Zar 1996) to model the proportional effects of relative habitat use by elk, cattle, and deer (i.e., number of pellet groups per stand; see below) in mountain meadows on RSH of Poa pratensis, which dominated the majority of meadows in LNF. We used stepwise regression because it is more conservative than information-theoretic model selection procedures (Murtaugh 2009). We included year as a dummy variable in models and used partial $R^{2}$ values to interpret how much each variable contributed to the overall variance of the model.

\section{Browse surveys}

We conducted browse surveys in April 2005 and 2006 prior to leaf-out of deciduous woody species. We randomly selected 25 replicate stands in mountain meadow, aspen, and thinned conifer, and 15 each in 2 large burns. As above, we selected these types based on preferences for elk and cattle foraging use in the montane habitats of LNF (Wright 2000; Hurd 2002).

We placed a single random transect within each stand replicate, parallel to the longest dimension of the stand. We used the Wyoming browse survey method (Wyoming Game and Fish Department 1982) to assess browse levels on key species. This involved sampling successive shrubs from the first shrub (closest to the random point), with each successive shrub being the closest shrub to the previous in the forward-facing 180 degrees (Wyoming Game and Fish Department 1982). We sampled successive shrubs until 50 live shrubs $\geq$ $0.25 \mathrm{~m}$ in height but $<2.54 \mathrm{~cm}$ dbh were examined per transect or until the stand had been completely traversed.

We identified all shrubs to species. We assessed percent use by examining all current annual growth (previous years) on each branch of the shrub between 0.25 and $2 \mathrm{~m}$ high, as that height range is within ungulate reach but usually too high for non-ungulate herbivores. We tallied the number of browsed shoots out of the total number of shoots examined for each shrub to determine frequency of use of browse. We calculated mean browse levels for all species encountered and used these to identify key browse species. We used a linear mixed model (West et al. 2014) with year as a random effect to test for differences among browse species, habitat types, and year, specifically testing the species $\times$ habitat type $\times$ year interaction. We used stepwise multiple regression (Zar 1996) as above to determine proportional use of browse species by elk, cattle, and mule deer with numbers of pellet groups per stand of each species used as predictor variables (see below) and browse levels as the outcome variable.

\section{Relative habitat use}

We assessed annual relative habitat use of elk, deer, and cattle by counting elk and deer pellet groups and cattle pats (hereafter, pellet groups) encountered within $2 \mathrm{~m}$ of a straight line between shrubs used in browse surveys until we covered $100 \mathrm{~m}$ (i.e., a $2 \times 100$-m belt transect). Pellet-group transects are adequate to assess relative use of habitats by wild and domestic ungulates (e.g., Cook 1966; Neff 1968; Collins and Urness 1984; Loft and Kie 1988; Halbritter and Bender 2011b) as shown by comparisons with radio telemetry-based approaches (Loft and Kie 1988). We also ran $2 \times 100$-m pelletgroup belt transects concurrently with vegetation surveys in autumn, and used these surveys to determine the degree of variation in use within key habitat types over the spring-autumn grazing period only. We used a linear mixed model (West et al. 2014) with year as a random effect to test for differences among species, habitat type, and year, specifically testing the species $\times$ habitat type $\times$ year interaction. We also used these data as inputs in regression models of browsing and grazing impacts (see above).

\section{Diets and diet quality}

We collected $\geq 10$ fecal samples per species per month, 1 May-31 October, 2004-2006, for analysis of diets and diet quality of elk and cattle. This period coincided with cattle use of LNF allottments. We collected only fresh fecal samples, usually those deposited within $24 \mathrm{~h}$. Diet composition samples were sent to the Wildlife Habitat Nutrition Lab (Washington State University, Pullman, WA, USA) for microhistological analysis (Sparks and Malechek 1968). We compared elk and cattle diets by major class (shrubs, conifer, forb, grass, sedge/rush) for the May-October period using Mann-Whitney tests (Zar 1996) and calculated Schoener's similarity index (Schoener 1970) for forage classes and for species comprising $\geq 1 \%$ of either elk or cattle spring-autumn diets.

We sent diet quality samples for cattle to the Grazing Animal Nutrition Lab (Texas A\&M University, College Station, TX, USA) for analysis using fecal near infrared reflectance spectroscopy (NIRS) to determine dietary digestibility (DD) and crude protein (CP) of cattle diets (Lyons and Stuth 1992). We analyzed diet quality by calculating monthly means for each year. We tested for differences among years using Kruskal-Wallis tests (Zar 1996).

We used percent ingesta-free body fat (BF) accrued by lactating female elk to estimate diet quality of elk during the spring-autumn season (Halbritter and Bender 2011a). 
Percent BF that lactating elk are able to accrue is strongly related to digestible energy content of diets and dietary thresholds for levels of BF have been established (Cook et al. 2004). We estimated BF for 16-23 radio-collared elk captured in late autumn at the approximate peak of accrual of BF as detailed in Halbritter and Bender (2011a, c). We estimated BF levels by measuring maximum subcutaneous fat thickness at the rump using a SonoVet 2000 ultrasound (Medison, Seoul, South Korea) and by determining body condition scores at the rump (Cook et al. 2001; Halbritter and Bender 2011a, c). We then extrapolated approximate digestible energy content of spring-autumn diets of elk based on mean level of BF from Cook et al. (2004).

To test for the influence of precipitation on diet quality we obtained monthly precipitation data for a weather station located in the northern quarter of our study area (Cloudcroft, Otero County, New Mexico, USA) from the Western Regional Climate Center (2007). We used linear regression (Zar 1996) to assess relationships between precipitation and cattle diet quality by modeling mean monthly $\mathrm{CP}$ and $\mathrm{DD}$ as a function of monthly precipitation. We also related the prior monthly precipitation to mean CP and DD for each month to determine if forage quality was affected by the amount of precipitation received the previous month.

\section{Results}

\section{Relative habitat use}

Relative habitat use of large herbivores differed $\left(F_{22,585}=\right.$ 24.1; $P<0.001)$, with elk $(P<0.001)$, cattle $(P<0.001)$, and deer $(P \leq 0.002)$ each showing differential use of habitat types (Table 1). In general, elk primarily used meadows and thinned conifer, cattle used meadows, and deer used burns and thinned conifer (Table 1). Cattle and deer use of burns was generally similar to use of other sites whereas elk use of burns was generally lower than meadows or thinned conifer (Table 1).
Spring-autumn pellet group surveys were conducted to determine the degree of variation in use within key habitat types over the spring-autumn grazing period only. Although we present data on relative use of habitat types in this period by species, the annual use data above should be used for stronger inferences of relative use by species. Similar to spring surveys, relative habitat use of large herbivores differed $\left(F_{25,646}=6.3 ; P<0.001\right)$. In 2005 , both elk and cattle use was significantly $(P \leq 0.008)$ greater in mountain meadows than in thinned conifer (Table 1). In 2005 , elk use did not differ $(P>0.621)$ among types, whereas cattle $(P=0.005)$ primarily used meadows and deer $(P<0.001)$ primarily used burns and thinned conifer (Table 1). In 2006, elk $(P<0.001)$ and cattle $(P<0.001)$ primarily used meadows and thinned conifer, while deer $(P=0.010)$ used thinned conifer and burns (Table 1).

Substantial variation existed within each habitat type in degree of relative habitat use. For all years, relative elk use ranged from 0 to 86 groups.stand ${ }^{-1}$ in mountain meadows, $0-22$ groups.stand ${ }^{-1}$ in thinned conifer, 0-32 groups.stand ${ }^{-1}$ in burns, and $0-35$ groups.stand ${ }^{-1}$ in aspen. Comparable groups.stand ${ }^{-1}$ for cattle were $0-34$, $0-13,0-25$, and $0-8$, respectively. For deer, ranges were $0-2,0-12,0-11$, and $0-4$, respectively.

\section{Vegetation composition and cover}

Ground cover differed $\left(F_{38,910}=162.7 ; P<0.001\right)$ in LNF; herbaceous plants $(P<0.001)$, bare soil $(P<0.065)$, litter $(P<0.001)$, rock $(P<0.068)$, and woody debris $(P<0.001)$ all varied among habitat types, except for woody debris in $2006(P>0.151)$. Meadows had the greatest plant cover each year while burns had the greatest plant cover among forested types (Table 2). Cover of herbaceous plants, soil, litter, rock, and woody debris also varied within habitat types in both $2005(P \leq 0.001)$ and $2006(P \leq 0.001)$. Herbaceous plant cover was greater in 2006 than 2005 in thinned conifer $(P=0.019)$, burned $(P=0.081)$, and meadow $(P=0.001)$ habitat types (Table 2$)$. Plant cover

Table 1 Mean number \pm SE of elk, cattle, and mule deer pellet groups by habitat types and season, Lincoln National Forest, 2004-2006

\begin{tabular}{|c|c|c|c|c|c|c|c|c|c|}
\hline \multirow[t]{2}{*}{ Season } & \multirow[t]{2}{*}{ Cover type } & \multicolumn{2}{|l|}{2004} & \multicolumn{3}{|l|}{2005} & \multicolumn{3}{|l|}{2006} \\
\hline & & Elk & Cattle & Elk & Cattle & Deer & Elk & Cattle & Deer \\
\hline \multirow[t]{4}{*}{ Annual } & Meadow & - & - & $12.8 \pm 1.8 X$ & $3.4 \pm 1.0 \mathrm{X}$ & $0.0 \pm 0.0 Y$ & $29.5 \pm 4.6 x$ & $10.6 \pm 1.9 x$ & $0.2 \pm 0.1 X$ \\
\hline & Aspen & - & - & $4.9 \pm 1.1 Y$ & $0.1 \pm 0.1 Y$ & $0.6 \pm 0.2 Y$ & $7.6 \pm 1.4 \mathrm{Y}$ & $0.6 \pm 0.4 Y$ & $0.6 \pm 0.2 X$ \\
\hline & Thinned conifer & - & - & $11.9 \pm 2.1 X$ & $1.0 \pm 0.4 Y$ & $1.4 \pm 0.5 X$ & $12.4 \pm 1.9 Y$ & $0.3 \pm 0.2 Y$ & $1.5 \pm 0.4 Y$ \\
\hline & Burn & - & - & $7.6 \pm 1.3 X Y$ & $3.3 \pm 1.1 X$ & $1.8 \pm 0.4 X$ & $7.4 \pm 1.4 Y$ & $0.9 \pm 0.4 Y$ & $2.4 \pm 0.7 Y$ \\
\hline \multirow[t]{4}{*}{ Spring-autumn } & Meadow & $12.3 \pm 3.4 \mathrm{~A}$ & $8.8 \pm 1.5 \mathrm{~A}$ & $10.4 \pm 2.9$ & $7.0 \pm 1.9 \mathrm{~A}$ & $0.2 \pm 0.1 \mathrm{~A}$ & $7.1 \pm 1.5 \mathrm{~A}$ & $5.8 \pm 1.3 \mathrm{~A}$ & $<0.1 \pm 0.1 \mathrm{~A}$ \\
\hline & Aspen & - & - & $4.8 \pm 0.9$ & $0.5 \pm 0.2 B$ & $0.4 \pm 0.2 \mathrm{~A}$ & $3.6 \pm 0.7 A B$ & $0.1 \pm 0.6 \mathrm{~B}$ & $0.4 \pm 0.2 \mathrm{AB}$ \\
\hline & Thinned conifer & $3.3 \pm 0.9 \mathrm{~B}$ & $2.4 \pm 0.8 \mathrm{~B}$ & $4.7 \pm 1.0$ & $1.0 \pm 0.4 \mathrm{~B}$ & $1.7 \pm 0.3 B$ & $5.2 \pm 0.5 \mathrm{~A}$ & $0.6 \pm 0.5 B$ & $1.0 \pm 0.2 C$ \\
\hline & Burns & - & - & $4.3 \pm 0.7$ & $1.6 \pm 0.6 \mathrm{~B}$ & $2.7 \pm 0.6 \mathrm{~B}$ & $1.4 \pm 0.4 \mathrm{~B}$ & $0.4 \pm 0.2 B$ & $0.8 \pm 0.4 B C$ \\
\hline
\end{tabular}


Table 2 Mean \pm SE percent ground cover by habitat type, Lincoln National Forest, autumn 2005-2006

\begin{tabular}{|c|c|c|c|c|c|c|c|c|c|c|}
\hline \multirow{2}{*}{$\begin{array}{l}\text { Habitat } \\
\text { type }\end{array}$} & \multicolumn{5}{|l|}{2005} & \multicolumn{5}{|l|}{2006} \\
\hline & Plant & Litter & Wood & Soil & Rock & Plant & Litter & Wood & Soil & Rock \\
\hline Aspen & $27.4 \pm 4.0 \mathrm{DX}$ & $60.5 \pm 4.2 C X$ & $7.6 \pm 1.0 \mathrm{BX}$ & $3.5 \pm 1.2 \mathrm{ABX}$ & $0.9 \pm 0.4 A X$ & $28.7 \pm 3.9 c x$ & $59.2 \pm 3.9 b x$ & $11.0 \pm 1.3 d$ & $1.3 \pm 0.1 \mathrm{ax}$ & $2.0 \pm 0.1 \mathrm{ax}$ \\
\hline Thinned & $23.9 \pm 2.6 \mathrm{DX}$ & $55.4 \pm 2.6 \mathrm{AX}$ & $14.0 \pm 2.1 \mathrm{EY}$ & $4.2 \pm 0.7 \mathrm{AX}$ & $2.5 \pm 0.5 B X$ & $34.5 \pm 3.5 c x$ & $48.2 \pm 3.3$ by & $11.0 \pm 1.2 \mathrm{~d}$ & $6.3 \pm 1.0$ ay & $4.8 \pm 0.6 a y$ \\
\hline Burned & $58.3 \pm 2.7 \mathrm{DY}$ & $11.2 \pm 1.3 \mathrm{ACY}$ & $5.6 \pm 0.9 B Z$ & $15.8 \pm 1.9 \mathrm{AY}$ & $9.3 \pm 1.4 \mathrm{ABY}$ & $70.1 \pm 2.7$ by & $6.2 \pm 0.8 \mathrm{az}$ & $8.1 \pm 1.1 \mathrm{a}$ & $7.6 \pm 1.1 \mathrm{az}$ & $11.0 \pm 2.0 \mathrm{az}$ \\
\hline Meadow & $84.2 \pm 1.7 \mathrm{BZ}$ & $2.1 \pm 0.8 \mathrm{AZ}$ & $0.5 \pm 0.2 \mathrm{AW}$ & $12.1 \pm 1.3 \mathrm{BZ}$ & $1.0 \pm 0.7 \mathrm{AX}$ & $91.7 \pm 1.2 \mathrm{cz}$ & $2.6 \pm 0.4 \mathrm{bz}$ & $1.7 \pm 0.2 b$ & $7.1 \pm 0.8 \mathrm{az}$ & $5.0 \pm 1.0$ by \\
\hline
\end{tabular}

was positively related to the amount of annual precipitation for thinned $\left(F_{1,48}=6.0, P=0.018, R^{2}=0.11 ; \beta=0.465\right.$ [SE $=0.192])$, burned $\left(F_{1,38}=8.7, P=0.005, R^{2}=0.19 ; \beta=\right.$ $0.553[\mathrm{SE}=0.188])$, and meadow habitat types $\left(F_{1,48}=\right.$ $12.2, P=0.001, R^{2}=0.20 ; \beta=0.329[\mathrm{SE}=0.094]$ ).

Poa pratensis was the most common plant species in all but the burned habitat type and comprised $>47 \%$ of the vegetation cover on mountain meadows (Table 3). Understory vegetation in burns was comprised primarily of Quercus spp. and various grasses, primarily Dactylis glomerata (2005) and Bromus inermis (2006) (Table 3).

Mean RSH of grasses were at or above recommended minimum stubble heights (Tables 4 and 5) except for Poa pratensis in mountain meadows in $2005(6.2 \mathrm{~cm}$ (90\% CI = 4.8-7.6)) (Table 4), which was below the standard of $6.4 \mathrm{~cm}$, and Bromus spp. in mountain meadows in 2006 (9.9 cm (90\% CI = 7.8-12.0) compared to a recommendation of $10.2 \mathrm{~cm}$ ) (Table 5). Neither of these deviations was statistically significant based on inclusion of recommended RSHs within $90 \%$ CIs of observed RSHs (Tables 4 and 5).

Habitat types did not vary $\left(F_{4,131}=1.3 ; P=0.264\right)$ in total shrub density due to extremely high variation among stand replicates. Burned conifer had the highest mean number of shrubs in 2005, but was dominated by less palatable shrubs including Quercus spp. and Robinia neomexicana. In 2006, greatest total shrub densities were in aspen stands (Table 6).

Habitat types differed in total tree density $\left(F_{4,102}=\right.$ 22.3; $P<0.001$ ) (Table 7). Aspen stands had the greatest mean tree density in both years $(P \leq 0.004)$ when compared to other managed or disturbed forests, which did not differ $(P \geq 0.383)$ (Table 7$)$. Burned stands had the lowest mean tree density, as the majority of each burn was characterized by near-complete stand replacement in which only snags remained.

Total herbaceous cover was negatively related $\left(F_{1,98}=\right.$ 111.8, $P<0.001, R^{2}=0.53 ; \beta=-1.122$ [SE = 0.106]) to percent canopy cover. Overall, conifer stands $(n=60)$ averaged $71.7 \%$ canopy cover (range $=28.5-97.7, \mathrm{SE}=2.0$ ).

\section{Browsing impacts}

We found a total of 5 browse species of moderate or higher palatability during browse transects: Holodiscus dumosis, Populus tremuloides, Acer glabrum, Symphoricarpos rotundifolius, and Prunus virginiana (Table 8). Palatable shrubs were rare in sampled stands, with only Holodiscus dumosis being found on $\geq 9$ transects in any cover type. Because of this, few species had the desired 50 plants per transect and none were present on all 25 replicate stand transects. Consequently power to detect differences in use was low for all species. Browse use varied $\left(F_{16,122}=3.7 ; \quad P<0.001\right)$ among comparisons (Table 8), although only use of Populus tremuloides

Table 3 Percent cover \pm SE of the most common plant species by habitat type, Lincoln National Forest, autumn 2005-2006

\begin{tabular}{|c|c|c|c|}
\hline \multirow{2}{*}{$\begin{array}{l}\text { Habitat } \\
\text { type }\end{array}$} & \multirow[t]{2}{*}{ Species } & \multicolumn{2}{|l|}{$\%$ Cover } \\
\hline & & 2005 & 2006 \\
\hline \multirow[t]{6}{*}{ Aspen } & Abies concolor & - & $13.6 \pm 4.0$ \\
\hline & Aster spp. & $13.5 \pm 3.4$ & $6.5 \pm 2.0$ \\
\hline & Fragaria vesca & $11.2 \pm 2.4$ & $10.4 \pm 1.1$ \\
\hline & Moss & $7.8 \pm 2.5$ & $8.3 \pm 2.8$ \\
\hline & Poa pratensis & $15.0 \pm 3.5$ & $13.6 \pm 4.0$ \\
\hline & Populus tremuloides & $8.9 \pm 4.3$ & - \\
\hline \multirow[t]{6}{*}{ Burn } & Artemisia ludoviciana & - & $7.4 \pm 3.2$ \\
\hline & Bromus inermis & $7.2 \pm 2.7$ & $12.8 \pm 4.7$ \\
\hline & Dactylis glomerata & $15.8 \pm 4.0$ & $5.2 \pm 1.2$ \\
\hline & Piptochaetium fimbriatum & $6.7 \pm 2.4$ & - \\
\hline & Poa pratensis & $6.1 \pm 2.6$ & $4.4 \pm 2.0$ \\
\hline & Quercus undulata & $13.3 \pm 3.9$ & $16.3 \pm 5.5$ \\
\hline \multirow[t]{6}{*}{ Meadow } & Achillea millefolium & $7.3 \pm 1.2$ & $3.7 \pm 0.1$ \\
\hline & Bromus spp. & - & $4.6 \pm 3.5$ \\
\hline & Bromus inermis & $3.9 \pm 2.1$ & - \\
\hline & Poa pratensis & $52.8 \pm 3.9$ & $47.4 \pm 5.4$ \\
\hline & Erodium cicutarium & $5.0 \pm 1.8$ & $7.2 \pm 2.4$ \\
\hline & Trifolium spp. & $3.4 \pm 1.4$ & - \\
\hline \multirow[t]{6}{*}{ Thinned } & Aster spp. & $12.0 \pm 2.9$ & $13.8 \pm 2.8$ \\
\hline & Bromus spp. & $7.3 \pm 1.7$ & $8.0 \pm 1.8$ \\
\hline & Fragaria vesca & $8.9 \pm 2.2$ & - \\
\hline & Moss & $5.4 \pm 1.2$ & $7.0 \pm 2.9$ \\
\hline & Poa pratensis & $27.5 \pm 4.6$ & $17.3 \pm 4.0$ \\
\hline & Quercus gambelii & $6.5 \pm 3.0$ & $8.0 \pm 4.3$ \\
\hline
\end{tabular}


Table 4 Mean percent grass cover \pm SE, residual stubble heights (RSH) of grasses $\pm 90 \% \mathrm{Cl}$, and recommended minimum RSH, Lincoln National Forest, autumn 2005, by habitat type

\begin{tabular}{|c|c|c|c|c|}
\hline Habitat type & Species & $\%$ Cover & $\mathrm{RSH}(\mathrm{cm})$ & Minimum \\
\hline \multirow[t]{4}{*}{ Aspen } & Bromus spp. & $50.4 \pm 6.9$ & $18.0 \pm 1.4$ & 10.2 \\
\hline & Poa pratensis & $35.0 \pm 5.6$ & $14.4 \pm 1.7$ & 6.4 \\
\hline & Bromus inermis & $4.7 \pm 3.6$ & $29.7 \pm 11.1$ & 10.2 \\
\hline & Bromus ciliates & $3.6 \pm 3.6$ & $20.3 \pm 0.0$ & 10.2 \\
\hline \multirow[t]{5}{*}{ Burn } & Dactylis glomerata & $29.9 \pm 6.6$ & $18.6 \pm 3.6$ & 10.2 \\
\hline & Piptochaetium fimbriatum & $14.2 \pm 5.0$ & $27.1 \pm 2.8$ & - \\
\hline & Poa pratensis & $8.6 \pm 3.7$ & $10.8 \pm 1.9$ & 6.4 \\
\hline & Bromus inermis & $8.3 \pm 2.8$ & $17.5 \pm 3.9$ & 10.2 \\
\hline & Piptochaetium pringlei & $7.1 \pm 3.9$ & $20.1 \pm 3.2$ & - \\
\hline \multirow[t]{3}{*}{ Meadow } & Poa pratensis & $78.8 \pm 5.4$ & $6.2 \pm 1.4$ & 6.4 \\
\hline & Bromus inermis & $3.9 \pm 2.2$ & $19.5 \pm 3.5$ & 10.2 \\
\hline & Agropyron trachycaulum & $3.8 \pm 2.4$ & $15.1 \pm 5.3$ & 10.2 \\
\hline \multirow[t]{3}{*}{ Thinned } & Poa pratensis & $40.7 \pm 5.2$ & $11.6 \pm 1.3$ & 6.4 \\
\hline & Bromus spp. & $38.3 \pm 5.1$ & $15.5 \pm 1.6$ & 10.2 \\
\hline & Achnatherum robustum & $6.0 \pm 3.9$ & $17.3 \pm 8.5$ & 10.2 \\
\hline
\end{tabular}

RSH standards from Allison et al. (2007)

showed a difference, with greater use in aspen stands than in thinned conifer in $2006(P=0.020)$. Too few browse plants were present in mountain meadows for analysis.

Year was not included in any model of relative use of browse in any habitat type $(P \geq 0.672)$. Relative use by elk, cattle and deer was positively related $\left(F_{3,17}=9.0 ; P=\right.$
$0.001)$ to browse levels in burns. Collectively, large herbivore use accounted for $61 \%$ of the variance in browse use with elk use accounting for $45 \%$, deer use $12 \%$, and cattle use $4 \%$ of the total variance. In thinned conifer, elk, cattle, and deer use $\left(F_{3,31}=1.21 ; P=0.322\right)$ was not related to use of primary browse species. Combined herbivory accounted for only $10 \%$ of the total variation in browse

Table 5 Mean percent grass cover \pm SE, residual stubble heights (RSH) of grasses $\pm 90 \% \mathrm{Cl}$, and recommended minimum RSH, Lincoln National Forest, autumn 2006, by habitat type

\begin{tabular}{|c|c|c|c|c|}
\hline Habitat type & Species & $\%$ Cover & $\mathrm{RSH}(\mathrm{cm})$ & Minimum \\
\hline \multirow[t]{3}{*}{ Aspen } & Bromus spp. & $62.7 \pm 8.9$ & $19.8 \pm 1.4$ & 10.2 \\
\hline & Poa pratensis & $36.0 \pm 9.2$ & $14.6 \pm 1.6$ & 6.4 \\
\hline & Agropyron trachycaulum & $1.2 \pm 1.2$ & $15.8 \pm 0.0$ & 10.2 \\
\hline \multirow[t]{5}{*}{ Burn } & Bromus inermis & $20.0 \pm 6.1$ & $17.3 \pm 2.8$ & 10.2 \\
\hline & Dactylis glomerata & $16.6 \pm 3.8$ & $19.8 \pm 2.3$ & 10.2 \\
\hline & Poa pratensis & $9.6 \pm 4.3$ & $12.7 \pm 7.3$ & 6.4 \\
\hline & Piptochaetium fimbriatum & $9.4 \pm 3.0$ & $24.3 \pm 2.6$ & - \\
\hline & Piptochaetium pringlei & $8.6 \pm 3.6$ & $32.8 \pm 6.0$ & - \\
\hline \multirow[t]{5}{*}{ Meadow } & Poa pratensis & $70.8 \pm 6.6$ & $6.4 \pm 1.4$ & 6.4 \\
\hline & Bromus spp. & $12.2 \pm 3.5$ & $9.9 \pm 2.1$ & 10.2 \\
\hline & Bromus inermis & $5.0 \pm 3.8$ & $10.8 \pm 27.4$ & 10.2 \\
\hline & Muhlenbergia fragilis & $4.4 \pm 3.8$ & $12.2 \pm 2.7$ & - \\
\hline & Achnatherum robustum & $3.9 \pm 2.4$ & $46.0 \pm 8.7$ & 10.2 \\
\hline \multirow[t]{4}{*}{ Thinned } & Bromus spp. & $39.5 \pm 6.5$ & $17.7 \pm 1.0$ & 10.2 \\
\hline & Poa pratensis & $27.5 \pm 6.0$ & $12.7 \pm 1.2$ & 6.4 \\
\hline & Piptochaetium pringlei & $5.7 \pm 2.9$ & $30.6 \pm 1.2$ & - \\
\hline & Piptochaetium fimbriatum & $4.1 \pm 3.6$ & $28.7 \pm 37.5$ & - \\
\hline
\end{tabular}


Table 6 Mean total woody stems $\leq 2.54 \mathrm{~cm}$ dbh \pm SE per hectare and mean total woody stems per hectare of the 5 most common species in aspen, burn, and thinned conifer habitat types, Lincoln National Forest, 2005-2006

\begin{tabular}{|c|c|c|c|}
\hline \multirow{2}{*}{$\begin{array}{l}\text { Habitat } \\
\text { type }\end{array}$} & \multirow[t]{2}{*}{ Species } & \multicolumn{2}{|c|}{ Stems $\cdot$ ha $^{-1}$} \\
\hline & & 2005 & 2006 \\
\hline \multirow[t]{8}{*}{ Aspen } & Abies concolor & 474 & 652 \\
\hline & Holodiscus dumosis & 177 & 307 \\
\hline & Pseudotsuga menziesii & 177 & 111 \\
\hline & Robinia neomexicana & 111 & - \\
\hline & Ribes spp. & 99 & - \\
\hline & Populus tremuloides & - & 107 \\
\hline & Acer glabrum & - & 93 \\
\hline & TOTAL & $1332 \pm 30$ & $1640 \pm 21$ \\
\hline \multirow[t]{6}{*}{ Burn } & Quercus undulata & 888 & 487 \\
\hline & Quercus gambelii & 726 & 305 \\
\hline & Robinia neomexicana & 300 & 250 \\
\hline & Juniperus deppeana & 156 & 174 \\
\hline & Holodiscus dumosis & 60 & 85 \\
\hline & TOTAL & $2394 \pm 26$ & $1406 \pm 46$ \\
\hline \multirow[t]{7}{*}{ Thinned } & Holodiscus dumosis & 203 & 361 \\
\hline & Quercus gambelii & 180 & 241 \\
\hline & Abies concolor & 138 & 138 \\
\hline & Pseudotsuga menziesii & 135 & 118 \\
\hline & Robinia neomexicana & 39 & - \\
\hline & Symphoricarpos rotundifolius & - & 82 \\
\hline & TOTAL & $822 \pm 39$ & $1262 \pm 26$ \\
\hline
\end{tabular}

levels. Of this total, cattle use accounted for $6 \%$, elk $4 \%$, and deer $<1 \%$. In aspen stands, combined herbivore relative use was positively related $\left(F_{3,45}=3.1 ; P=0.038\right)$ to browse use and accounted for a combined $17 \%$ of the variance in total browse levels. Individually, elk, cattle, and deer use accounted for $12 \%, 4 \%$, and $1 \%$ of the total variance in browse use in aspen stands, respectively.

\section{Grazing impacts}

Year was not included in models of RSH of Poa pratensis $\left(F_{1,47}<0.1 ; P=0.894\right)$. Residual stubble height of Poa pratensis was negatively related to relative use of all herbivores $\left(F_{3,45}=2.4 ; P=0.085\right)$, which accounted for $14 \%$ of the total variance in RSH of Poa pratensis. Cattle use accounted for $10 \%$, elk use $4 \%$, and deer use $<1 \%$ of the variance in $\mathrm{RSH}$ of Poa pratensis.

\section{Diets and diet quality}

Across years, spring-autumn diets of elk were comprised of significantly more deciduous browse $(U=1.7$; $P=0.080)$ and forbs $(U=2.2 ; P=0.032)$ than were cattle diets, but less grass $(U=1.7 ; P=0.080)$ and sedge $(U=$
Table 7 Mean total number of trees per hectare \pm SE and number of trees per hectare for the 5 most common species in aspen, burn, and thinned conifer habitat types, Lincoln National Forest, 2005- 2006

\begin{tabular}{|c|c|c|c|}
\hline \multirow{2}{*}{$\begin{array}{l}\text { Habitat } \\
\text { type }\end{array}$} & \multirow[t]{2}{*}{ Species } & \multicolumn{2}{|l|}{ Trees $\cdot$ ha $^{-1}$} \\
\hline & & 2005 & 2006 \\
\hline \multirow[t]{7}{*}{ Aspen } & Populus tremuloides & 559 & 512 \\
\hline & Abies concolor & 222 & 396 \\
\hline & Pseudotsuga menziesii & 158 & 196 \\
\hline & Quercus gambelii & 67 & 73 \\
\hline & Robinia neomexicana & 48 & - \\
\hline & Acer glabrum & - & 30 \\
\hline & TOTAL & $1149 \pm 16$ & $1254 \pm 13$ \\
\hline \multirow[t]{7}{*}{ Burn } & Pinus ponderosa & 44 & 39 \\
\hline & Pseudotsuga menziesii & 31 & 20 \\
\hline & Juniperus deppeana & 21 & 39 \\
\hline & Quercus gambelii & 15 & - \\
\hline & Abies concolor & 11 & 7 \\
\hline & Pinus strobiformis & - & 20 \\
\hline & TOTAL & $137 \pm 81$ & $131 \pm 49$ \\
\hline \multirow[t]{8}{*}{ Thinned } & Pseudotsuga menziesii & 158 & 174 \\
\hline & Abies concolor & 89 & 136 \\
\hline & Populus tremuloides & 28 & - \\
\hline & Quercus gambelii & 13 & 25 \\
\hline & Pinus ponderosa & 8 & - \\
\hline & Pinus strobiformis & - & 39 \\
\hline & Picea engelmannii & - & 28 \\
\hline & TOTAL & $329 \pm 30$ & $454 \pm 22$ \\
\hline
\end{tabular}

$1.7 ; P=0.080)$. Use of conifers did not differ $(U=1.1 ; P=$ 0.282) (Table 9). Elk and cattle diets were not significantly similar (Schoener's index $<0.60$ ) for either major forage classes $(0.57)$ or individual forage species (0.54).

Digestibility of cattle diets was $69.2 \%(\mathrm{SE}=0.5)$, $68.0 \%(\mathrm{SE}=0.4)$, and $67.4 \%(\mathrm{SE}=0.6)$ for May-October 2004, 2005, and 2006, respectively, and did not differ $\left(H_{2}=4.0 ; P=0.132\right)$ among years. $C P$ levels varied annually $\left(H_{2}=12.7 ; P=0.002\right)$ in diets and were $14.1 \%(\mathrm{SE}=$ $0.5), 13.2 \%(\mathrm{SE}=0.3)$, and $14.7 \%(\mathrm{SE}=0.4)$ for 2004 , 2005 , and 2006, respectively. CP was higher $(P=0.004)$ in cattle diets in 2006 as compared to 2005; no other year comparisons differed $(P \geq 0.101)$.

Monthly precipitation was positively related to $\mathrm{CP}$ in cattle diets $\left(F_{1,13}=6.0, P=0.029, R^{2}=0.32 ; \beta=1.186\right.$ [SE $=0.484])$, but not DD of cattle diets $\left(F_{1,13}=0.5 ; P=\right.$ 0.506). Precipitation lagged 1 month resulted in similar effects, showing a positive relationship with $\mathrm{CP}\left(F_{1,13}=\right.$ 6.2, $\left.P=0.028, R^{2}=0.32 ; \beta=1.220[\mathrm{SE}=0.492]\right)$ and no effect on DD $\left(F_{1,13}=0.3 ; P=0.612\right)$. 
Table 8 Percent utilization \pm SE of key browse species on Lincoln National Forest by cover-type. Only use of Populus tremuloides in 2006 differed between aspen and thinned conifer habitat types

\begin{tabular}{lllllcc}
\hline \multirow{2}{*}{$\begin{array}{l}\text { Year } \\
\text { Habitat }\end{array}$} & \multicolumn{3}{l}{ Browse species } & & & \\
\cline { 3 - 6 } & H. dumosis & P. tremuloides & A. glabrum & P. virginiana & S. rotundifolius \\
\hline 2005 & Aspen & $59.5 \pm 4.1$ & $87.5 \pm 12.5$ & $67.5 \pm 12.0$ & $73.1 \pm 1.8$ & $74.9 \pm 3.6$ \\
& Thinned & $64.0 \pm 5.2$ & - & - & $72.1 \pm 27.9$ & $18.9 \pm 5.9$ \\
2006 & Aspen & $77.1 \pm 2.1$ & $75.4 \pm 8.0$ & $67.5 \pm 12.0$ & $57.9 \pm 0.7$ & $56.5 \pm 7.2$ \\
& Thinned & $73.4 \pm 3.2$ & $56.5 \pm 7.2$ & $69.0 \pm 7.7$ & $44.0 \pm 23.8$ & $43.4 \pm 8.7$ \\
\hline
\end{tabular}

Lactating cow elk were able to accrue $10.5 \%(\mathrm{SE}=0.6)$, $11.4 \%(\mathrm{SE}=0.7)$, and $8.9 \%(\mathrm{SE}=0.7) \mathrm{BF}$ by autumn 2003, 2004, and 2005, respectively (Halbritter and Bender 2011a, c). Levels of BF that lactators were able to achieve differed $\left(H_{2}=5.9, P=0.053\right)$ among years; 2005 was lower than 2003 and 2004, which were similar. This level of condition corresponded to diet qualities in the marginal to good range (digestibility $=56-63 \%)$ based on criteria from penned elk (Cook et al. 2004).

\section{Discussion}

Herbivory by large herbivores had varying impacts on LNF. Whereas high levels of browsing suggested that herbivores, primarily elk, could potentially deleteriously

Table 9 Mean \pm SE percent occurrence in spring-autumn diets of elk and cattle by forage class, 2004-2006

\begin{tabular}{|c|c|c|c|c|c|c|c|c|c|}
\hline \multirow[t]{2}{*}{ Class } & \multirow[t]{2}{*}{ Species } & \multicolumn{4}{|l|}{ Elk } & \multicolumn{4}{|l|}{ Cattle } \\
\hline & & 2004 & 2005 & 2006 & Mean & 2004 & 2005 & 2006 & Mean \\
\hline \multirow[t]{7}{*}{ Shrubs } & Acer glabrum leaf & 3.2 & 1.5 & 1.0 & $1.9 \pm 0.7$ & - & - & - & 0 \\
\hline & Holodiscus dumosis, leaf & 2.3 & 0.5 & 0.3 & $1.1 \pm 0.6$ & - & - & - & 0 \\
\hline & Quercus spp. leaf & 24.8 & 30.6 & 20.2 & $25.2 \pm 3.0$ & 6.5 & 2.9 & 9.3 & $6.2 \pm 1.9$ \\
\hline & Salix spp. leaf & 17.4 & 13.9 & 7.1 & $12.8 \pm 3.0$ & - & - & - & 0 \\
\hline & Salix spp. stem & 1.9 & 0.9 & 1.7 & $1.5 \pm 0.3$ & - & - & - & 0 \\
\hline & Symphoricarpos rotundifolius leaf & 2.4 & 0.7 & 0.8 & $1.3 \pm 0.5$ & - & - & - & 0 \\
\hline & TOTAL & 55.2 & 51.5 & 34.2 & $46.9 \pm 6.5 \mathrm{~A}$ & 7.4 & 4.3 & 10.7 & $7.5 \pm 1.8 \mathrm{~B}$ \\
\hline Conifer & TOTAL & 0.2 & 1.1 & 1.1 & $0.8 \pm 0.3$ & 0.1 & 0.4 & 0.5 & $0.3 \pm 0.1$ \\
\hline \multirow[t]{4}{*}{ Forbs } & Achillea millefolium & 0.8 & 1.1 & 1.7 & $1.2 \pm 0.3$ & 0.8 & 1.8 & 1.8 & $1.5 \pm 0.3$ \\
\hline & Erigeron spp. & 1.8 & 1.4 & 0.7 & $1.3 \pm 0.3$ & - & - & - & $0.1 \pm 0.1$ \\
\hline & Geranium spp. & 1.7 & 1.0 & 0.5 & $1.0 \pm 0.3$ & - & - & - & $0.6 \pm 0.4$ \\
\hline & TOTAL & 8.2 & 11.5 & 7.8 & $9.1 \pm 1.2 \mathrm{~A}$ & 6.5 & 6.5 & 6.8 & $6.6 \pm 0.1 \mathrm{~B}$ \\
\hline \multirow[t]{13}{*}{ Grass } & Agropyron spp. & 1.6 & 0.7 & 1.8 & $1.4 \pm 0.3$ & 17.2 & 12.1 & 11.5 & $13.6 \pm 1.8$ \\
\hline & Agrostis spp. & - & - & - & $0.7 \pm 0.5$ & 5.4 & 4.9 & 5.4 & $5.2 \pm 0.2$ \\
\hline & Bouteloua spp. & - & - & - & 0 & 4.3 & 1.8 & 1.0 & $2.4 \pm 1.0$ \\
\hline & Bromus spp. & 5.1 & 7.3 & 13.6 & $8.7 \pm 2.5$ & 5.6 & 8.4 & 6.9 & $6.9 \pm 0.8$ \\
\hline & Dactylis glomerata & - & - & - & $0.8 \pm 0.2$ & 0.8 & 1.2 & 1.3 & $1.1 \pm 0.2$ \\
\hline & Agropyron trachycaulum & 0.0 & 0.9 & 3.7 & $1.5 \pm 1.1$ & - & - & - & $0.7 \pm 0.1$ \\
\hline & Muhlenbergia spp. & - & - & - & $0.9 \pm 0.2$ & 7.3 & 3.9 & 5.0 & $5.4 \pm 1.0$ \\
\hline & Oryzopsis spp. & - & - & - & 0 & 2.2 & 0.5 & 0.7 & $1.1 \pm 0.5$ \\
\hline & Poa fendleriana & - & - & - & - & 1.9 & 1.7 & 0.4 & $1.3 \pm 0.5$ \\
\hline & Poa pratensis & - & - & - & - & 21.2 & 30.7 & 29.2 & $27.0 \pm 3.0$ \\
\hline & Poa spp. & 20.4 & 16.7 & 24.1 & $20.4 \pm 2.1$ & 23.1 & 32.4 & 29.6 & $28.3 \pm 2.8$ \\
\hline & Stipa spp. & 1.6 & 0.6 & 1.2 & $1.1 \pm 0.3$ & 5.6 & 7.5 & 7.0 & $6.7 \pm 0.6$ \\
\hline & TOTAL & 32.2 & 29.8 & 49.5 & $37.2 \pm 6.2 \mathrm{~A}$ & 75.0 & 77.1 & 72.2 & $74.8 \pm 1.4 \mathrm{~B}$ \\
\hline \multirow[t]{2}{*}{ Sedge/Rush } & Carex spp. & 4.3 & 4.9 & 5.7 & $5.0 \pm 0.4$ & 10.6 & 10.3 & 7.6 & $9.5 \pm 0.9$ \\
\hline & TOTAL & 4.3 & 4.9 & 5.7 & $5.0 \pm 0.4 \mathrm{~A}$ & 10.9 & 11.5 & 9.6 & $10.6 \pm 0.6 \mathrm{~B}$ \\
\hline
\end{tabular}


impact browse resources, grazing on mountain meadows - the area of contention on LNF (Hurd 2002; Hurd et al. 2004; Halbritter and Bender 2011b) - indicated few impacts of herbivory. While relative habitat use of meadows by elk and cattle was generally equal to or higher than other habitat types, and conflicts can occur when wild and domestic ungulates concentrate their habitat use, significant variation existed in relative habitat use of individual meadows by elk and cattle (CV's > 80) on LNF. Additionally, no grass species was significantly overutilized based on minimum RSH recommendations (Allison et al. 2007). Further, RSH of Poa pratensis (and all grasses; Halbritter 2007) on meadows was not strongly correlated with relative habitat use of large herbivores. Relative habitat use by cattle was the primary large herbivore effect but accounted for $\leq 10 \%$ of the variation in RSH of Poa pratensis among meadows despite the high prevalence $(75 \%)$ of grasses in general and Poa pratensis (55 \%) in cattle diets. Thus, much of the variation in RSH of Poa pratensis was attributable to factors other than ungulate presence, including elevation, aspect, precipitation, location, size, and small herbivore use (Halbritter 2007; L. Bender, unpublished data).

Despite the conflict over perceived overutilization of meadows on LNF, our results illustrate that much of the variation in RSHs among meadows was associated with factors other than relative habitat use of meadows by large herbivores. Further, meadows were not grazed beyond sustainable levels. Although large herbivore presence is readily apparent to observers and thereby receives significant attention (Halbritter and Bender 2011b), other less obvious environmental factors affected RSHs on LNF. Management actions, such as selection of monitoring sites to assess degree of herbivore utilization of meadows vegetation, need to consider effects of other environmental variables (as well as the large variation in relative habitat use of meadows by large herbivores across LNF) or they risk erroneous conclusions as to the effect of large herbivores on mountain meadows. For example, while a limited number of meadows we surveyed could have indicated that grazing (or other factors) was substantially negatively affecting RSH of grasses, meadows across the LNF landscape showed no grazingrelated impacts that affected sustainability. Selection and use of key sites as management indicators should represent landscape dynamics if such sites are used to drive decisions on management of landscapes, rather than to identify localized areas of conflict.

Relative habitat use by elk and cattle was generally equal to or higher in mountain meadows than other habitat types, and conflicts can occur when wild and domestic ungulates concentrate their use in vegetation types that represent a small proportion of the total available habitat. Because meadows comprised a small and declining proportion $(<5 \%)$ of the total habitat available to ungulates in LNF, and relative habitat use (and, consequently, potential for herbivory) varied greatly, it is particularly important to identify those factors affecting use of meadows. On LNF, recommended management solutions to perceived overutilization of meadows (e.g., decreased stocking rates for cattle and reductions in elk populations throughout the game management unit; Wright 2000; Hurd 2002; Hurd et al. 2004) may have less than anticipated effects on RSH of meadows across the LNF landscape because of the weak correlations between RSH and relative habitat use of ungulates. Knowing which factors affect meadow use can aid management decisions by identifying those meadows where management practices would be most beneficial. For example, cattle primarily used meadows closer to water and with gentler slopes (Halbritter and Bender 2011b), so increasing the number or quality of these meadows could potentially alleviate use of some of the mountain meadows that receive relatively high use. Moreover, large differences in use of meadows, related to factors influencing distribution of elk and cattle (Halbritter 2007; Halbritter and Bender 2011b), further indicate that generalized reductions of elk and cattle numbers may have little effect alleviating perceived conflicts over use of meadows.

In contrast, utilization of browse on LNF was comparable to areas experiencing high herbivory (e.g., use of Salix spp. in Rocky Mountain National Park [70 \%-> 90 \%; Zeigenfuss et al. 1999] and use of Populus tremuloides in Yellowstone National Park [77-90 \%; National Research Council 2002]. Relative habitat use by elk was correlated with the majority of the variation of browsing in all cover types (6-45\%; total combined use by cattle and deer accounted for only an additional $4-16 \%$ of the variation in browsing intensity), reflecting the high prevalence of browse (34-55\%) in elk diets annually. The relatively high utilization suggested that elk might be exerting a substantial impact on browse species in LNF. Ungulate herbivory can have significant impacts on regenerating Populus tremuloides and other browse species which can influence the effectiveness of management practices such as prescribed burns and timber harvests (Cannon et al. 1987; Wisdom et al. 2006). Such effects may be magnified when browse is limited, such as on LNF (Table 6).

However, the relative scarcity of woody browse species in stands suggests that use rates might simply be high because little palatable browse was available in forested stands of LNF. Canopy cover in LNF negatively affected both herbaceous understory cover and woody stem densities, and canopy cover, particularly of conifer dominated stands, was high (71 \%). Lack of browse (as well 
as herbaceous understory) may also contribute to elk use of mountain meadows, because forested stands, particularly conifer stands, provided little food for elk, deer, or cattle (Tables 3 and 6). Lack of browse (and forest encroachment of meadows) is a result of altered historical disturbance (especially fire) regimes and decreased timber harvest, which has increased stand densities and decreased the quantity of open habitats on LNF (Kaufmann et al. 1998; Frost et al. 2007). Increasing quantity (by overstory thinning or removal [McConnell and Smith 1970; Wallmo et al. 1972; Woods et al. 1982; Dahms and Geils 1997; Halbritter and Bender 2011a]) and quality (by prescribed burning in conjunction with harvesting [Covington et al. 1997; Dahms and Geils 1997; Halbritter and Bender 2011a]) of palatable browse could potentially alter elk distribution in LNF and lower use of other habitat types such as mountain meadows (Halbritter and Bender 2011a, b). The effect of overstory removal with or without burning was illustrated in the comparatively high relative habitat use of thinned and burned stands by all large herbivores (Table 1).

Competition results from shared use of limited resources resulting in decreased performance of one or more competitors (Holechek 1980; Vavra et al. 1989; Miller 2002). Quality of cattle diets on LNF were more than adequate for reproduction and growth (National Research Council 2000), and these levels of diet quality were consistent with variable but generally light overall use of forage and low population densities and stocking rates. Overall, elk diet quality was in the marginal to good range based on penned elk studies (Cook et al. 2004), which likely underestimate diet quality obtained by free-ranging elk because of the greater energetic costs faced by the latter. Although the lower quality seen in 2005 could result in reduced growth and productivity according to performance studies of penned elk (Cook et al. 2004), data from Halbritter and Bender (2011c) indicated no strong nutritional effects on elk survival or productivity. The only evident effect was on calf survival, which was mostly associated with above normal precipitation during parturition. Calf survival is more susceptible to slight changes in environmental variation than adult survival and thus is one of the first population parameters to show any evidence of resource limitations (Gaillard et al. 2000).

Thus, the few nutritional limitations seen on LNF appeared to result from density-independent effects, as 2005, the year of lowest fat levels in lactating elk (8.9 \% versus $10.4-11.5 \%$ ), received only $82 \%$ of normal precipitation (only $77 \%$ of normal during the growing season). That precipitation rather than competition or density effects was likely the driving factor affecting these nutritional relationships was reflected in both plant cover and nutrient load (CP levels) showing significantly positive relationships with precipitation. Precipitation affected forage quality as reflected by lower CP levels of cattle diets in 2005. Further, an increase in precipitation in 2006 resulted in increased plant cover in thinned, burned, and mountain meadow cover types. However, despite lower forage quality in 2005, diet quality of both elk and cattle on LNF did not significantly limit individual performance (National Research Council 2000; Cook et al. 2004; Halbritter and Bender 2011c). Nor were diets of elk and cattle strongly similar (Schoener's index $\leq 0.57$ ). Because the ultimate effect of competition is reduced fitness of one or all competitors due to reduced resource capture lowering individual and population performance (Holechek 1980; Vavra et al. 1989; Miller 2002), the relatively high diet quality achieved by cattle on LNF (and to a lesser extent elk), the lack of any significantly decreased performance parameter for elk, and low diet similarity all indicate that co-occurrence had little ultimate impact on either large herbivore.

\section{Conclusions}

Both elk and cattle acquired diets on LNF that generally did not limit individual or population performance, indicating that neither elk nor cattle populations were limited by condition of the extant plant community or by competition between the species. Nor was grazing by elk or cattle negatively impacting sustainability of meadows, the area of greatest contention on LNF. Diet composition and forage use also collectively indicated that at current stocking levels, no competition was occurring between elk and cattle on LNF. Thus, generalized reductions in stocking rates of cattle or elk populations were not warranted with respect to sustainability of meadows, and in fact increased numbers of both elk and cattle could be supported by current habitat conditions on LNF. However, with greater numbers of animals on the landscape comes a higher potential for impacts on plant communities unless large herbivore distribution is managed or available forage increased. Currently, only with browse utilization in burns was relative habitat use by large ungulates able to directly account for $>50 \%$ of the variation in levels of browse utilization or RSH of Poa pratensis on LNF. Because use of palatable woody browse was high in all habitat types, likely due to low availability of browse, recruitment of palatable woody plants could potentially be reduced in LNF if saplings are too heavily browsed and woody browse remains relatively limited in forest cover types. Managers need to consider other factors in addition to large herbivore grazing if greater residual biomass is desired on meadows in LNF.

Elk used thinned conifer comparably to mountain meadows, despite the low occurrence of palatable browse species in thinned conifer stands. Burns were used by all large herbivores. Because understory herbaceous cover and woody densities were strongly negatively related to 
overstory canopy cover in LNF, management aimed at decreasing forest overstory to increase woody and herbaceous understories (forage quantity), preferably in conjunction with prescribed burns (to increase forage quality), could have strong effects in altering herbivore use of LNF landscapes. Rehabilitating encroached meadows by reestablishing historic disturbance regimes could also increase distribution, quantity, and quality of open habitats. Providing additional or higher quality foraging habitats could alter elk and cattle distribution away from meadows receiving relatively greater use, and thus alleviate perceived conflicts between elk and cattle, and herbivory and other land uses (Halbritter and Bender 2011b).

\section{Competing interests}

The authors declare that they have no competing interests.

\section{Authors' contributions}

All authors contributed equally to all aspects of this study and manuscript. Both authors read and approved the final manuscript.

\section{Authors' information}

$\mathrm{HH}$ is Wildlife Specialist and LCB is Senior Research Scientist with NMSU.

\section{Acknowledgements}

We thank the U.S. Forest Service, Rocky Mountain Elk Foundation, New Mexico Department of Game and Fish, and several private entities for funding this project. The New Mexico State University, Agricultural Experiment Station provided additional financial support. We thank B. Barrett, T. Kamienski, J. Piasecke, E. Watters, and M. Weisenberger for their contributions to this project. All activities were performed in accordance with NMSU Institutional Animal Use and Care Committee Permit No. 2003-023.

Received: 6 May 2015 Accepted: 11 September 2015

Published online: 16 September 2015

\section{References}

Allison CD, Holechek JL, Baker TT, Boren JC, Ashcroft N, Fowler JM (2007) Rapid assessment methodology for proactive rangeland management. Rangelands 29(2):45-50

Alstad KP, Welker JM, Williams SA, Trlica MJ (1999) Carbon and water relations of Salix monticola in response to winter browsing and changes in surface water hydrology: an isotopic study using $\delta^{13} \mathrm{C}$ and $\delta^{18} \mathrm{O}$. Oecologia 120:375-385

Bender LC (2007) Demographics, habitat use, and foraging of sympatric elk and cattle on Lincoln National Forest and Game Management Unit 34. Final Report, New Mexico Cooperative Fish and Wildlife and Research Unit, Las Cruces, NM

Cannon SK, Urness PJ, DeByle NV (1987) Habitat selection, foraging behavior, and dietary nutrition of elk in burned aspen forest. J Range Manage 40:433-438

Carpenter LH, Decker DJ, Lipscomb JF (2000) Stakeholder acceptance capacity in wildlife management. Hum Dim Wild 5:5-19

Caughley G (1979) What is this thing called carrying capacity? In: Boyce MS, Hayden-Wing LD (eds) North American elk: ecology, behavior, and management. University of Wyoming Press, Laramie, WY, pp 2-8

Chadde SW, Kay CE (1991) Tall-willow communities on Yellowstone's northern range: a test of the "natural-regulation" paradigm. In: Keiter RB, Boyce MS (eds) The Greater Yellowstone ecosystem: redefining America's wilderness heritage. Yale University Press, New Haven, CT, pp 231-261

Collins WB, Urness PJ (1984) The pellet-group census technique as an indicator of relative habitat use: a response to Leopold et al. Wildl Soc Bull 12:327

Cook CW (1966) Factors affecting utilization of mountain slopes by cattle. J Range Manage 19:200-204

Cook RC, Cook JG, Murray DL, Zager P, Johnson BK, Gratson MW (2001) Development of predictive models of nutritional condition for Rocky Mountain elk. J Wildl Manage 65:988-997
Cook JG, Johnson BK, Cook RC, Riggs RA, Delcurto T, Bryant LD, Irwin LR (2004) Effects of summer-autumn nutrition and parturition date on reproduction and survival of elk. Wildl Monogr 155:1-61

Cottam G, Curtis JT (1956) The use of distance measures in phytosociological sampling. Ecology 37:451-460

Covington WW, Fule PZ, Moore MM, Hart SC, Kolb TE, Mast JN, Sackett SS, Wagner MR (1997) Restoring ecosystem health in ponderosa pine forests of the Southwest. J For 95:23-29

Dahms CW, Geils BW (1997) An assessment of forest ecosystem health in the Southwest, General Technical Report RM-GTR-295. U.S. Forest Service Rocky Mountain Research Station, Ft. Collins, CO

De Mazancourt C, Loreau M, Abbadie L (1998) Grazing optimization and nutrient cycling: when do herbivores enhance plant production? Ecology 79:2242-2252

Fleischner TL (1994) Ecological costs of livestock grazing in western North America. Cons Biol 8:629-644

Frost R, Roberts C, Hyatt G, Fowler J (2007) Mountain meadow and open area encroachment in the Lincoln Forest, Sacrament grazing allotment. Report 69. Range Improvement Task Force, New Mexico State University, Las Cruces, NM

Gaillard J-M, Festa-Bianchet M, Yoccoz NG, Loison A, Toïgo C (2000) Temporal variation in fitness components and population dynamics of large herbivores. Ann Rev Ecol System 31:367-393

Georgiadis NJ, Ruess RW, McNaughton SJ, Western D (1989) Ecological conditions that determine when grazing stimulated grass production. Oecologia 81:316-322

Halbritter H (2007) Demographics, habitat use, and foraging of sympatric elk and cattle on Lincoln National Forest. M.S. Thesis, New Mexico State University, Las Cruces, NM

Halbritter H, Bender LC (2011a) Elk habitat quality in the southern Sacramento Mountains, New Mexico. Southwest Nat 56: 1-8

Halbritter H, Bender LC (2011b) Contrasting observation and transect based models of cattle distribution on Lincoln National Forest, New Mexico. Range Ecol Manage 64: 514-520

Halbritter H, Bender LC (2011c) Condition, survival, and productivity of elk in the Sacramento Mountains of southern New Mexico. Southwest Nat 56: 305-314

Hamilton EW III, Giovannini MS, Moses SA, Coleman JS, McNaughton SJ (1998) Biomass and mineral element responses of a Serengeti short-grass species to nitrogen supply and defoliation: compensation requires a critical [N]. Oecologia 116:407-418

Holechek JL (1980) Concepts concerning forage allocation to livestock and big game. Rangelands 2:158-159

Hurd BJ (2002) Effects of big game and livestock on plant cover, composition, and herbaceous biomass in logged areas of the Sacramento Mountains. M.S. Thesis, New Mexico State University, Las Cruces, NM

Hurd BJ, Boren JC, Baker TT (2004) Foraging relationships of big game and livestock and effects on plant communities in logged areas of the Lincoln National Forest, Final Report, Resource joint venture Agreement RMRS-99150RJVA. New Mexico State University, Range Improvement Task Force, Las Cruces, NM

Kaufmann MR, Huckaby LS, Regan CM, Popp J (1998) Forest reference conditions for ecosystem management in the Sacramento Mountains, General Technical Report RMRS-GTR-19. U.S. Forest Service Rocky Mountain Research Station, Ft. Collins, CO

Kay CE (1997) Viewpoint: Ungulate herbivory, willows, and political ecology in Yellowstone. J Range Manage 50:139-145

Kay CE, Bartos DL (2000) Ungulate herbivory on Utah aspen: assessment of longterm exclosures. J Range Manage 53:145-153

Lemmon RE (1956) A spherical densitometer for estimating forest overstory density. For Sci 2:314-320

Loft ER, Kie JG (1988) Comparison of pellet-group and radio triangulation methods for assessing deer habitat use. J Wildl Manage 52:524-527

Lyons RK, Stuth JW (1992) Fecal NIRS equations for predicting diet quality of freeranging cattle. J Range Manage 45:238-244

McConnell BR, Smith JG (1970) Response of understory vegetation to ponderosa pine thinning in eastern Washington. J Range Manage 23:208-212

McNaughton SJ (1976) Serengeti migratory wildebeest: facilitation of energy flow by grazing. Science 191:92-94

Miller W (2002) Elk interactions with other ungulates. In: Toweill DE, Thomas JW (eds) North American elk; ecology and management. Smithsonian Institution Press, Washington D.C, pp 435-447 
Murtaugh PA (2009) Performance of several variable-selection methods applied to real ecological data. Ecol Lett 12:1061-1068

National Research Council (2000) Nutrient requirements of beef cattle, 7th edn. National Academy Press, Washington D.C

National Research Council (2002) Ecological dynamics on Yellowstone's Northern Range. National Academy Press, Washington D.C

Neff DJ (1968) The pellet-group count technique for big game trend, census, and distribution: a review. J Wild Manage 32:597-614

Peinetti HR, Kalkhan MA, Coughenour MB (2002) Long-term changes in willow spatial distribution on the elk winter range of Rocky Mountain National Park (USA). Land Ecol 17:341-354

Relva MA, Veblen TT (1998) Impacts of introduced large herbivores on Austrocedrus chilensis forests in northern Patagonia, Argentina. For Ecol Manage 108:27-40

Riggs RA, Cook JG, Irwin LL (2005) Management implications of ungulate herbivory in Northwest forest ecosystems. In: Wisdom MJ (ed) The Starkey Project: a synthesis of long-term studies of elk and mule deer. Alliance Communications Group, Lawrence, KS, pp 217-232

Ripple WJ, Larsen EJ (2000) Historic aspen recruitment, elk, and wolves in northern Yellowstone National Park, USA. Biol Cons 95:361-370

Ripple WJ, Larsen EJ, Renkin RA, Smith DW (2001) Trophic cascades among wolves, elk, and aspen on Yellowstone National Park's northern range. Biol Cons 102:227-234

Schoener TW (1970) Nonsynchronous spatial overlap of lizards in patchy habitats. Ecology 51:408-418

Severson KE, Medina AL (1983) Deer and elk habitat management in the Southwest. J Range Manage Monogr 2:1-64

Sparks DR, Malechek JC (1968) Estimating percentage dry weight in diets using a microscopic technique. J Range Manage 21:264-265

Stewart KM, Bowyer RT, Ruess RW, Dick BL, Kie JG (2006) Herbivore optimization by North American elk; consequences for theory and management. Wildl Monogr 167:1-24

Vavra M (2005) Livestock grazing and wild life: developing compatibilities. Range Ecol Manage 58:128-134

Vavra M, Mclnnis M, Sheehy D (1989) Implications of dietary overlap to management of free-ranging large herbivores. Proc West Sect Amer Soc Anim Sci 40:489-495

Wallmo OC, Regelin WC, Reichert DW (1972) Forage use by mule deer relative to logging in Colorado. J Wild Manage 36:1025-1033

West BT, Welch KB, Galecki AT (2014) Linear mixed models: a practical guide using statistical software, 2nd edn. CRC Press, Boca Raton, FL

Western Regional Climate Center (2007) Climate summary, Cloudcroft, NM. http://wrcc.dri.edu. Accessed 1 Jun 2007

Wisdom MJ, Vavra M, Boyd JM, Hemstrom MA, Ager AA, Johnson BK (2006) Understanding ungulate herbivory-episodic disturbance effects on vegetation dynamics: knowledge gaps and management needs. Wildl Soc Bull 34:283-292

Woods RF, Betters DR, Mogren EW (1982) Understory herbage production as a function of Rocky Mountain aspen stand density. J Range Manage 35:380-381

Wright BD (2000) Ungulate distribution and forage utilization in the Sacramento Mountains. Dissertation, New Mexico State University, Las Cruces, NM

Wyoming Game and Fish Department (1982) Handbook of biological techniques. Wyoming Game and Fish Department, Laramie, WY

Zar JH (1996) Biostatistical analysis, 3rd edn. Prentice Hall, Upper Saddle River, NJ

Zeigenfuss LC, Singer FJ, Bowden D (1999) Vegetation responses to natural regulation of elk in Rocky Mountain National Park, Biological Science Report USGS/BRD/BSR-1999-003. U.S. Government Printing Office, Denver, CO

\section{Submit your manuscript to a SpringerOpen ${ }^{\circ}$ journal and benefit from:}

- Convenient online submission

- Rigorous peer review

- Immediate publication on acceptance

- Open access: articles freely available online

- High visibility within the field

- Retaining the copyright to your article

Submit your next manuscript at $\gg$ springeropen.com 